\title{
KETERKAITAN CITRA MEREK, HARGA DAN KUALITAS PRODUK TERHADAP KEPUTUSAN PEMBELIAN TINJAUAN SISTEMATIS LITERATURE REVIEW
}

\author{
Dapit Alex Sander ${ }^{*}$ \\ Arianis Chan² \\ Herwan Abdul Muhyi ${ }^{3}$ \\ 1,2,3 Universitas Padjajaran \\ “Corresponding Author: dapit19001@mail.unpad.ac.id
}

\begin{abstract}
Much research on purchasing decisions refers to price, product quality and brand image. This study aims to complement previous research. Research that has explored the relationship of brand image, price and product quality to purchasing decisions. The purpose of this study was to determine the operationalization of the influence of brand image, price, and product quality. This study will describe the interrelationships between variables in purchasing decisions in the context of marketing science. This study uses a systematic review process, namely an in-depth literature review of the results of 23 articles based on certain keywords and limitations. Based on the review produced a model that describes the influence of brand image, price and product quality on purchasing decisions. It is expected to be a reference and adoption of an approach to marketing activities. Future research is suggested to have more than one database and use more sources of research articles published over 10-20 years. It is hoped that future research with broad observations and results on how science continues to develop.
\end{abstract}

Keywords: brand image, price, product quality, purchasing decisions.

\section{PENDAHULUAN}

Pelanggan adalah pusat pembuat keputusan, para pesaing tidak kenal lelah dalam memuaskan pelanggan dan mencari keunikan untuk membedakannya dari pesaing mereka. Kepuasan pelanggan adalah perjalanan yang tidak pernah berakhir, karena outputnya adalah keputusan pembelian (Uddin et al., 2015). Saat ini, kehidupan manusia tak terlepas dari jual beli atau transaksi. Sebelum melakukan pembelian seseorang biasanya akan melakukan keputusan pembelian terlebih dahulu terhadap suatu produk. 
Keputusan pembelian adalah tahap dalam keputusan pembeli, dimana konsumen memutuskan benar-benar membeli dan terlibat langsung dalam pengambilan keputusan untuk membeli produk yang ditawarkan oleh penjual (Pradana \& Wisnu, 2021). Keputusan pembelian menjadi penting saat banyaknya pilihan dengan fungsi dan kategori produk atau jasa sejenis. Konsumen harus memutuskan produk yang akan dibeli ditengah banyaknya berbagai pilihan produk yang beredar di pasaran.

Dalam pengambilan keputusan, pembeli akan menentukan apa yang akan dibeli atau tidak melakukan pembelian berdasarkan aktivitas sebelumnya, baik dalam bisnis online maupun offline. Sebelum melakukan keputusan pembelian, konsumen memperhatikan merek, harga produk, reputasi bisnis, kesetaraan produk dan layanan toko fisik secara langsung (C. Wang et al., 2021) keakraban, desain (Widyastutir \& Said, 2017), citra merek, kualits produk, kepuasan pelanggan (Waluya et al., 2019) harga (Ravaja et al., 2013), iklan (Adnan et al., 2019), dan merek produk, harga yang wajar, layanan (Ngo et al., 2019). Pada produk tahan lama yang memiliki generasi produk seperti kulkas, mobil, televisi berwarna, konsumen dalam mengambil keputusan akan mementingkan harga dan kualitas produk (Jia \& Zhang, 2013).

Dalam literatur keputusan pembelian, terdapat empat dimensi yang sering muncul antara lain, perilaku konsumen, persepsi konsumen, kinerja merek, dan strategi harga. Dalam proses pembelian, konsumen acap kali melihat citra merek, citra toko, desain, harga dan kualitas produk sebelum memutuskan untuk membeli. Beberapa sudut pandang ditemukan hubungan signifikan citra merek, harga dan kualitas produk menjadi perhatian pada keputusan pembelian (Waluya et al., 2019, Widyastutir \& Said, 2017, Uddin et al., 2015, Wang et al., 2021). Kondisi konsumen dalam pengambil keputusan meliputi faktor eksternal, internal dan pemasaran. Budaya, subkultur, kelompok, situasi, kelas sosial dan keluarga berada dalam faktor eksternal. Faktor internal yaitu persepsi, sikap, pengetahuan, kepribadian, gaya hidup, keterlibatan dan peran. Sedangkan faktor pemasaran adalah produk, kemasan estetika, promosi, distribusi, pelayanan dan harga (Gunawan et al., 2019).

Citra merek adalah faktor terbesar yang mempengaruhi keputusan pembelian (Waluya et al., 2019). Dalam membandingkan citra merek terdapat merek global dan merek lokal. Pada dasarnya konsumen lebih memilih merek global, kecuali merek lokal sudah memiliki reputasi global, akan menjadi pilihan keputusan pembelian (Winit et al., 2014a). Pada kasus Nigeria, merek global tetap menjadi pilihan padahal kualitas produk sama dengan produk lokal. Merek global dipilih karena memiliki varian harga berbedabeda dibanding merek lokal. Konsumen cendrung menyukai merek global yang harganya murah (Obih \& Baiyegunhi, 2017).

Tingginya keterpilihan produk global dipengaruhi oleh citra merek yang baik. Terjadi juga pada merek global yang mempunyai citra yang baik, memenangkan persaingan dalam produk kategori sejenis. Jika produk adalah produk kategori makanan pokok, maka perlu kebijakan pemerintah untuk membatasi merek global (impor). Kondisi persaingan 
keterpilihan merek lokal dan merek global pada makanan pokok perlu campur tangan pemerintah (Obih \& Baiyegunhi, 2017).

Ketepatan persepsi konsumen bervariasi tergantung pada pentingnya merek dalam keputusan pembelian untuk kategori produk tertentu (Boyle et al.,2018). Harga tinggi akan dapat menimbulkan persepsi kualitas yang lebih tinggi (Ravaja et al., 2013). Akan tetapi terkadang harga tidak selalu mencerminkan dimensi kualitas produk yang berbeda. Meskipun produk dengan harga lebih tinggi memiliki spesifikasi produk dan tampilan visual yang unggul, tidak menunjukkan kinerja semua elemen, seperti kesesuaian, daya tahan dan performa (Ghaani Farashahi et al., 2018).

Harga menjadi faktor yang harus dikendalikan secara harmonis dengan tujuan yang ingin dicapai oleh perusahaan (Widyastutir \& Said, 2017). Harga yang rendah dapat meningkatkan kewajaran harga yang dirasakan dan memperkuat niat beli yang lebih tinggi dari strategi harga yang diadakan. Sensitivitas harga memiliki hubungan moderat secara signifikat terhadap nilai kualitas dan konsumen (Othman \& Rahman, 2016). Pada keputusan pembelian secara online konsumen enggan membeli produk mahal hanya dengan informasi yang ditransfer secara digital. Konsumen cendrung membeli lebih banyak produk murah secara online seiiring dnegan akumulasi pengalaman belanja online mereka. (Kim \& Krishnan, 2015).

Sementara korelasi antara harga dan kualitas adalah moderat. Perusahaan yang berbasis industri penting memperhatikan dan mengelola kualitas produk untuk mengkomunikasikan aspek keunggulan kepada pelanggan (Waluya et al., 2019). Dalam penjualan produk tingkat kualitas rendah, akan membuat penjualan menurun, sedangkan produk yang kualitas tinggi akan membuat penjualan meningkat (Hou et al., 2021). Dalam produk atau jasa yang tidak dikenal, konsumen acap kali menjadikan harga sebagai patokan kualitas produk. Sementara citra merek yang dibangun dengan produk berkualitas tinggi dengan indikator kepuasan pelanggan akan meningkatkan keputusan pembelian (Waluya et al., 2019). Berbagai studi ditemukan bahwa kepuasan pelanggan diiringi dengan kepercayaan akan membentuk loyalitas pelanggan yang sangat berguna untuk pertumbuhan bisnis jangka panjang. (Eid, 2011).

Setiap produk yang mempunyai fisik, tidak dapat dengan mudah dievaluasi sebelum dibeli. Untuk melihat kualitas produk, konsumen harus membeli suatu produk terlebih dahulu (K. Li et al., 2019). Konsumen awal tidak mengamati kualitas produk sebelum membeli, tetapi dapat mempelajarinya setelah membeli. Selanjutnya akan hanya mengetahui gambaran umum ketika konsumen awal membagikan ulasan produk (Jiang \& Yang, 2019).

Untuk produk teknologi, elektronik dan otomotif, konsumen khawatir tentang risiko kegagalan produk dan tingginya biaya perbaikan dan penggantian. Produsen biasanya menawarkan garansi produk, Cakupan garansi yang luas akan dinilai produk berkualiatas tinggi. Terjadinya kegagalan produk akan menimbulkan biaya yang besar terhadap produsen. Produsen saingan yang berkualitas buruk dan tingkat kegagalan tinggi yang 
tidak mampu membayar biaya kerugian akan tergerus dari persaingan. Masa garansi dan isi garansi dari produsen dapat digunakan produsen sebagai sinyal kualitas produk (K. Li et al., 2019).

Kehati-hatian konsumen terlihat pada perilaku konsumen sebelum memutuskan untuk membeli. Faktor emosional dan motivasi memainkan peran yang lebih besar dalam menentukan keputusan pembelian untuk produk merek nasional (Ravaja et al., 2013, Pradana \& Wisnu, 2021). Berbeda dengan keputusan pembelian secara online, hampir seluruh konsumen online tidak yakin dengan kualitas produk subjektif misalnya, kecocokan, rasa menggunakan atau memakai dan tekstur bahan karena tidak adanya informasi pengalaman. Konsumen membeli produk dengan keidakpastian produk yang tinggi (Kim \& Krishnan, 2015). Pengalaman belanja offline melalui toko fisik dapat membantu konsumen melihat kualitas produk. Sementara untuk belanja online tanpa isyarat fisik konsumen mengalami ketidakpastian produk. Konsumen hanya dapat melihat kualitas produk melalui pengalaman belanja dengan melihat ulasan produk, dan deskripsi produk(Kim \& Krishnan, 2015).

\section{TELAAH PUSTAKA}

Keterkaitan antara citra merek, harga dan kualitas produk pada keputusan pembelian dengan keputusan pembelian bersifat moderasi. Citra merek, harga dan kualitas produk dapat menjadi stimulus, merangsang, dan mendorong konsumen untuk melakukan keputusan pembelian. Citra merek adalah representasi dari keseluruhan persepsi yang terbentuk dari informasi dan pengetahuan tentang merek. Erat kaitannya dengan sikap dan keyakinan yang membentuk pilihan (preferensi) terhadap suatu merek (Wijaya, 2012). Semakin positif citra merek, maka semakin terbentuk ekuitas merek, sehingga keputusan konsumen untuk melakukan pembelian lebih tinggi. (Sallam, 2016). Citra merek yang sukses akan menciptakan kesan positif dalam benak konsumen, dapat mengurangi risiko pembelian dan mempengaruhi keputusan pembelian.

Harga adalah sejumlah uang yang ditagihkan atas suatu produk atau jasa atau jumlah dari nilai yang ditukarkan para pelanggan untuk memperoleh manfaat dari memiliki atau menggunakan produk atau jasa (Kotler \& Amstrong, 2012). Setiap konsumen berharap mendapatkan kepuasan dari produk, sehingga merasakan kepuasan harga. Secara tradisional harga menjadi penentu utama pilihan pembeli. Di era digital harga dengan mudah dapat dilihat dan dibandingkan. Produk dengan harga tinggi akan membuat keputusan pembelian jadi rendah. Sebaliknya harga rendah akan membuat keputusan pembelian tinggi. Namun harga yang tinggi dengan kualitas tinggi akan membantu peningkatan keputusan pembelian menjadi tinggi.

Kualitas produk adalah keseluhan ciri dan karakter yang menunjukkan kemampuannya untuk memuaskan kebutuhan konsumen. Produk yang berkualitas akan memenuhi dan melebihi harapan konsumen (Kotler \& Keller, 2016). Kualitas tinggi menjadi kunci utama dalam memenangkan persaingan yang kompetitif. Tapi hanya 
sebahagian kecil yang memanfaatkan bersaing kualitas karena membutuhkan penghitungan biaya kualitas, tim interfungsional, rekayasa keandalan dan kontrol kualitas statistik(Garvin, 1984). Konsumen yang puas dengan kualitas produk berpotensi melakukan pembelian berulang (purchase intention) dan setia pada merek (brand loyalty).

Keputusan pembelian merupakan sikap seseorang untuk membeli maupun menggunakan suatu produk untuk memuaskan dirinya dan kesediaan bertanggung jawab atas risiko yang akan diambilnya. Sebelum melakukan keputusan pembelian. konsumen memperhatikan merek, harga produk, reputasi bisnis, kesetaraan produk (Wang et al., 2021), citra merek, kualitas produk, kepuasan pelanggan (Waluya et al., 2019), harga produk dan layanan (Ngo et al., 2019).

\section{METODE}

Penelitian ini menggunakan analisis sistematika komisi (Tikito \& Souissi, 2019). Yaitu analisis sistematis terhadap "praktik ilmu dasar" yang ditujukan untuk melacak bias dengan melakukan aktivitas detail mulai dari ulasan, pengambilan keputusan, metode, debat dan laporan untuk pencarian literatur mendalam yang diterbitkan pada artikel ilmiah. Meta-analisis, memainkan peranan utama dalam menyediakan metode statistik untuk mensisntesis hasil, merupakan salah satu prosedur dalam tinjauan sistematis.

Penelitian ini mengadopsi pendekatan yang digunakan (Wu \& Wu, 2016) dalam meninjau dan menganalisis literatur. Pada tinjauan terlihat langkah-langkah pada metode penelitian yang disediakan pada Gambar 1. Langkah pertama adalah memutuskan pertanyaan penelitian dan mengidentifikasi kata kunci (Gomezelj, 2019).

Tujuan dari penelitian ini adalah untuk melihat hubungan dalam keputusan pembelian melalui variabel citra merek, harga dan kualitas produk. Pertanyaan penelitian dalam sistematika tinjauan fokus pada prioritas seperti yang terlihat pada gambar 1. Berdasarkan pertanyaan penelitian, pencarian kata kunci dalam database antara lain, merek, citra merek, harga, kualitas produk, persepsi konsumen, perilaku konsumen dan keputusan pembelian.

Database berasal dari online scopus yang dikumpulkan sebagai situs jurnal yang terintegrasi dan terpercaya jurnal ilmiah internasional dan publikasi dari disiplin ilmu yang berbeda. Pada 10 oktober 2021, pencarian diambil. Artikel penelitian dicari oleh sarana database online scopus yang diterbit pada tahun 2011-2021. String pencarian telah diatur seperti yang ditunjukkan pada tabel 1 bersama dengan hasil pencarian.Untuk melihat tren penelitian terbaru, para peneliti memilih tahun 2021 dan sepuluh tahun yang lalu sebagai waktu yang dianggap terlalu singkat untuk melihat evolusi penelitian dalam harga, kualitas produk dan citra merek pada keputusan pembelian. Selain itu, jika periode pengambilan lebih lama, itu akan menghasilkan lebih banyak pos yang ada, pada gilirannya membutuhkan waktu yang lebih lama waktu penelitian. 
Kedua, persyaratan inklusi dan ekslusi ditetapkan sebagai berikut: 1) publikasi ilmiah dalam bentuk publikasi dari jurnal marketing dan bisnis. 2) karya ilmiah dengan ruang lingkup harga, kualitas produk, citra merek dan keputusan pembelian. 3) artikel bahasa inggris. 4) penelitian terkait. Relevansi dinilai dengan diskusi kelompok tentang peneliti melalui membaca seluruh isi artikel. Penelitian diurutkan dengan menghapus artikel yang tidak mengikuti persyaratan. Seperti artikel kuliah atau artikel non jurnal lainnya. Artikel yang membahas salah satu topik utama saja dan artikel yang tidak ditulis dalam bahasa inggris. Mengikuti persyaratan ini, terdapat 23 artikel penelitian yang dipilih dan didiskusikan.

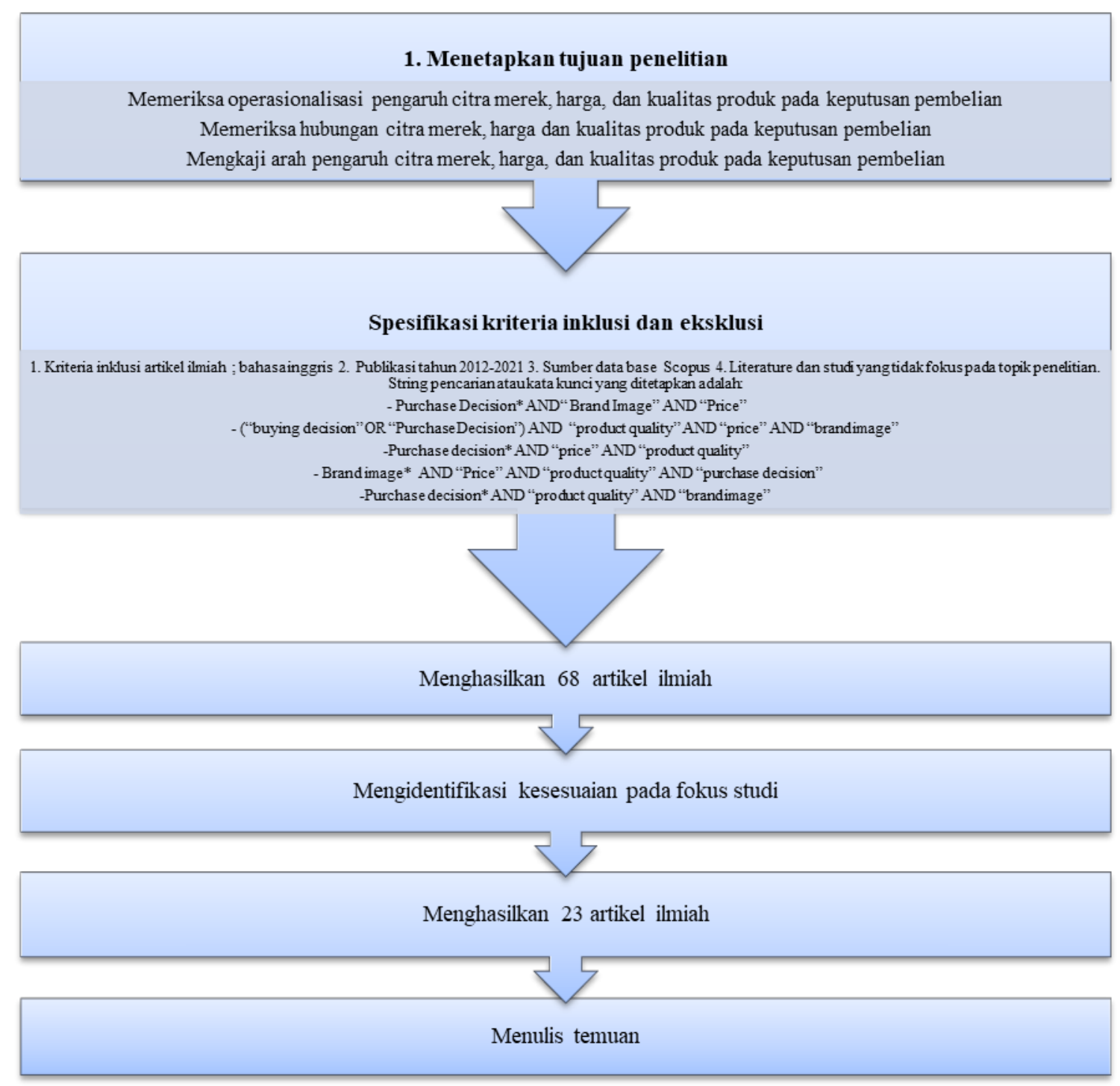

Gambar 1. Langkah-Langkah Penelitian 
Tabel 1. Hasil Pencarian Pada Database Scopus

\begin{tabular}{|c|c|c|c|}
\hline String pencarian & $\begin{array}{l}\text { Hasil } \\
\text { pencarian }\end{array}$ & $\begin{array}{l}\text { Sesuai secara } \\
\text { elektronik } \\
\text { dengan } \\
\text { persyaratan } \\
\text { inklusi }\end{array}$ & $\begin{array}{l}\text { Penilaian } \\
\text { berdasarkan } \\
\text { diskusi } \\
\text { komunitas }\end{array}$ \\
\hline $\begin{array}{l}\text { Purchase Decision* } \quad \text { AND“Brand } \\
\text { Image" AND "Price" }\end{array}$ & 41 & 20 & 6 \\
\hline $\begin{array}{l}\text { ("buying decision" OR "Purchases } \\
\text { Decision") AND "product quality" AN } \\
\text { "price" AND "brand image" }\end{array}$ & 4 & 2 & 1 \\
\hline $\begin{array}{l}\text { purchase decision* AND "price" AND } \\
\text { "product quality" }\end{array}$ & 124 & 39 & 14 \\
\hline $\begin{array}{l}\text { Brand image* AND "Price" AND } \\
\text { "product quality" AND "purchase } \\
\text { decision" }\end{array}$ & 6 & 3 & 1 \\
\hline $\begin{array}{l}\text { purchase decision* AND "product } \\
\text { quality" AND "brand image" }\end{array}$ & 14 & 4 & 1 \\
\hline
\end{tabular}

ANALISIS DATA DAN PEMBAHASAN

Hasil dari analisis sistematis adalah dibagi menjadi empat bagian. Pertama ada diskusi tentang penerbitan jurnal dan karakteristiknya dari sampel yang digunakan. Kedua mengidentifikasi operasionalisasi keputusan pembelian, citra merek, harga, dan kualitas produk. Ketiga dalam keputusan pembelian, penelitian mengekplorasi peran mediasi citra merek, harga dan kualitas produk. Keempat, menjelaskan mekanisme interferensi yang mempengaruhi hubungan timbal balik antara keempat variabel tersebut.

Sumber utama jurnal berasal dari Journal Of Retailing And Consumer Service, International Of Supply Chain Management, International Journal Production Economics. Selama tahun 2011 sampai tahun 2021, riset terkait citra merek, harga dan kualitas produk pada keputusan pembelian sebagian besar diterbitkan pada tahun 2018, dan setidaknya pada 2013, 2017 dan 2019. Sementara tidak satupun publikasi yang terkait dengan subjek pada tahun 2012 dan 2016, (dapat dilihat pada Gambar 2).

Sebaran data ditujukkan pada gambar 3 berdasarkan metode, bentuk bisnis dan topik yang sedang dibahas. Menurut data statistik, pendekatan kuantitatif adalah yang paling umum digunakan, dengan total 10 publikasi dengan topik diskusi paling banyak adalah tentang consumer behavior, brand performance dan creativity and innovation, pendekatan kualitatif dengan topic pricing strategy, consumer behavior, creativity and innovation, perpaduan kuantitaif dan kualitatif (mix method) dengan topik pricing 
strategy, consumen behavior dan brand performance, analisis literature atau tinjauan sistematis dengan topik bahasan consumer bahaviour dan sales.

Berdasarkan tabel 2 dapat dilihat bahwa dari tahun 2012 Hingga tahun 2021 penelitian terkait citra merek, harga, kualitas produk dan keputusan pembelian telah sebagian besar dilakukan di Amerika Serikat (6), China (5), Indonesia (3) dan India (2). Ada beberapa penelitian yang dilakukan secara umum tidak berlaku ke satu Negara karena hanya membahas literature review.

Bidang industri secara umum (general) menjadi subjek banyak studi termasuk umum (Singh et al., 2018), (Verma \& Gupta, 2014),(Winit et al., 2014), (Ravaja et al., 2013),(Jiang \& Yang, 2019), (Park et al., 2020), teknologi dan internet (Y. Li et al., 2013), (Uddin et al., 2015), (C. Wang et al., 2021), (Jia \& Zhang, 2013), (Hou et al., 2021) manufaktur (Widyastutir \& Said, 2017), (Kumar \& Kapoor, 2017), (Jia \& Zhang, 2013), (K. Li et al., 2019), service (Casado-Díaz et al., 2017), (R. Wang et al., 2019), otomotif (Sulaiman \& Chau, 2021), institution (Pradana \& Wisnu, 2021),(Obih \& Baiyegunhi, 2017), (Chen et al., 2021), dan SMEs (Ghaani Farashahi et al., 2018), (Boyle et al., 2018)

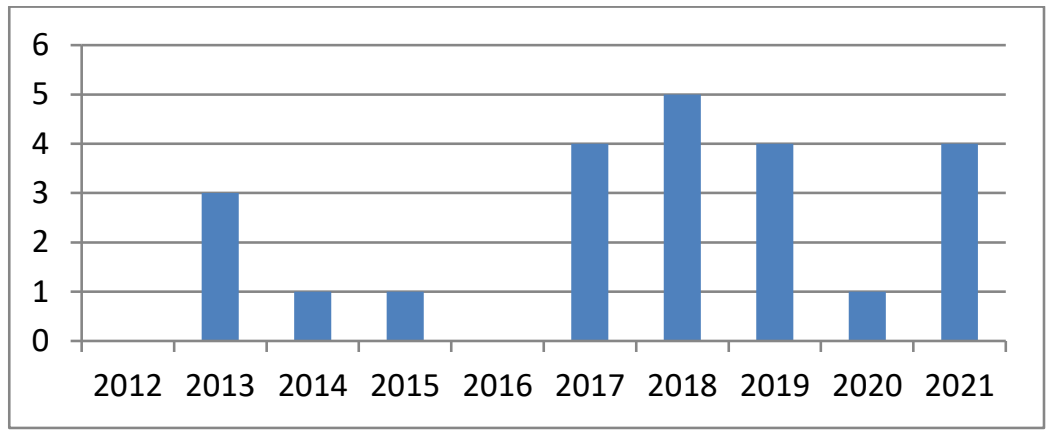

Gambar 2. Jumlah Publikasi Per Tahun

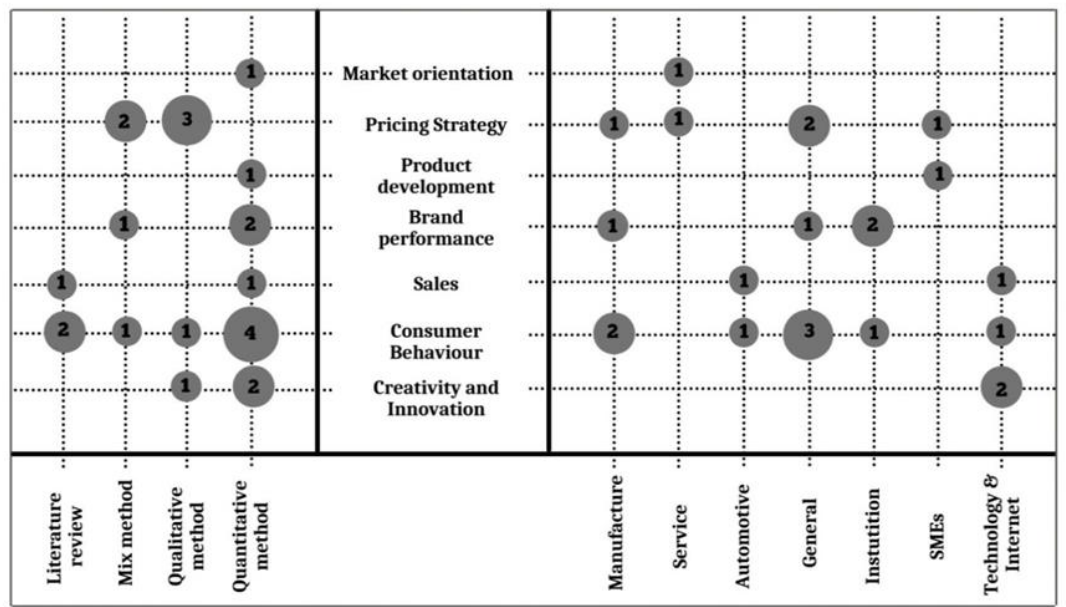

Gambar 3. Distribusi data berpusat pada metode penelitian, jenis bisnis dan topik yang dibahas 
Tabel 2. Jumlah Publikasi Berdasarkan Negara

\begin{tabular}{lll}
\hline No & Negara & Jumlah \\
\hline 01 & Amerika Serikat & 6 \\
02 & China & 5 \\
03 & Indonesia & 3 \\
04 & India & 2 \\
05 & Malaysia & 1 \\
06 & Nigeria & 1 \\
07 & Finlandia & 1 \\
08 & Bangladesh & 1 \\
09 & Australia & 1 \\
10 & Spanyol & 1 \\
11 & Thailand & 1 \\
\hline
\end{tabular}

Era digital berpotensi mengubah perilaku konsumen menciptakan model bisnis baru yang memberikan nilai lebih dan efisiensi. Banyak perilaku konsumen yang belum pernah terjadi sebelumnya dan tidak terduga. Bagi generasi yang akrab dengan teknologi dan internet, belanja online menjadi sangat penting dalam kesehariannya. Kemajuan teknologi membuat dunia bisnis mengalami perubahan yang cepat. Konsumen menuntut suatu produk sesuai dengan selera, kebutuhan dan daya belinya. Dalam melakukan keputusan pembelian, konsumen melakukan proses pertimbangan terlebih dahulu (Widyastutir \& Said, 2017). Internet saat ini adalah isyarat penting bagi suatu merek bisnis dengan menyoroti informasi yang dihasilkan dari rekan-rekan melalui electronic word of mouth (e-WOM) dalam proses pengambilan keputusan konsumen.(Casado-Díaz et al., 2017). Untuk memenangkan persaingan, perusahaan harus menampilkan produk terbaik untuk memenuhi selera konsumen yang terus berkembang dan berubah. Penting bagi perusahaan untuk mengetahui perilaku konsumen yang menentukan keputusan pembelian, (Widyastutir \& Said, 2017). Sebagaimana dikatakan Kotler \& Keller, proses pembelian konsumen meliputi alur identifikasi masalah, pencarian informasi, evaluasi alternatif, keputusan pembelian dan perilaku setelah pembelian (Kotler \& Keller, 2016).

Tugas pemasar adalah memahami perubahan yang terjadi dari setiap langkah perilaku, sikap masyarakat, faktor situasi yang tidak terduga dan asumsi risiko yang mempengaruhi keputusan pembelian dan tingkat kepuasan konsumen setelah pembelian, manfaaat dan arah tindakan perusahaan (Widyastutir \& Said, 2017). Sebagai contoh, pada produk kategori tahan lama, konsumen sangat peka dan sensitif terhadap harga dan kualitas produk. Setiap produk dibeli karena fungsi fisiknya yang berguna dan siklus hidup produk relatif lama. Seperti mobil, laptop, peralatan olahraga, barang rumah tangga, kulkas televisi berwarna dan lain sebagainya. Akan tetapi perkembangan terbaru, generasi produk begitu cepat membuat, konsumen juga memperhatikan karakteristik produk, paket khusus, kenyamanan belanja. (Jia \& Zhang, 2013)

Terlihat pada ketika Apple Inc memperkenalkan smartphone berkemampuan internet dan multimedia pertama pada 9 januari 2007 yang dirilis pada 29 juni 2007. 
Selang waktu kurang dari 5 tahun, Apple juga merilis iPhone, IPhone $3 \mathrm{G}$, iPhone3GS, iPhone 4. Pada tanggal 14 oktober 2011 juga telah merilis iPhone generasi ke-5. Membuat konsumen tidak hanya memperhatikan harga dan kualitas produk. Tapi juga memperhatikan karakteristik produk dan generasi produk yang diluncurkan (Jia \& Zhang, 2013). Walaupun terjadi perubahan cepat terhadap produk dan perilaku konsumen. Pada dasarnya konsumen mempertimbangkan semua petunjuk yang tersedia. Informasi tersebut seringkali diperoleh dari internet (Casado-Díaz et al., 2017).

Ditengah perkembangan teknologi dan digitalisasi, konsumen sangat cermat sebelum melakukan keputusan pembelian. Keputusan pembelian secara langsung dipengaruhi oleh kesadaran merek dan secara tidak langsung oleh citra merek dan ekuitas merek (Widyastutir \& Said, 2017). Electronic word of mouth (EWOM) sering jadikan rujukan dalam keputusan pembelian (Casado-Díaz et al., 2017). Setidaknya ada lima faktor kunci dalam melihat merek produk yaitu kesadaran harga, variabilitas kualitas, citra merek, citra toko dan persepsi diri (Singh et al., 2018).

Diantara banyaknya variabel yang mempengaruhi keputusan pembelian, Citra merek menjadi faktor yang paling signifikan diikuti sebagai variabel intervening dalam keputusan pembelian, (Singh et al., 2018). Konsumen dalam melihat citra merek, akan melihat label merek, sebagai alat komunikasi efektif dan berguna mempengaruhi keputusan pembelian pelanggan saat ini dan calon pelanggan. Khususnya konsumen muda sangat mementingkan merek dan akan membacanya sebelum membuat keputusan pembelian, (Kumar \& Kapoor, 2017). Ketika berinteraksi dengan merek melalui kunjungan toko atau konsumsi aktual. Merek yang kuat dan familiar akan menimbulkan aktivasi emosi positif. Sedangkan merek yang lemah dan tidak dikenal akan menimbulkan aktivasi emosi negatif (Ravaja et al., 2013). Untuk memasuki pasar, setiap merek harus memiliki positioning produk. Strategi utama yang mempengaruhi taktik bauran pemasaran untuk mencapai pembentukan citra merek jangka panjang. Positioning dapat dilihat dari keputusan penentuan posisi perusahaan yang dipengaruhi oleh karakteristik pasar dan konsumen seperti preferensi konsumen, perbedaan kualitas, persaingan dan perbedaan biaya produksi (Sajeesh \& Song, 2017).

Untuk konsumen muda lebih cendrung menginginkan merek global. Meskipun berasal dari merek lokal, persepsi merek global dapat berdampak positif pada evaluasi merek. Perusahaan dapat menumbuhkan citra merek global dengan menekankan isyarat global (Winit et al., 2014). Merek lokal dipandang sebagai "ikon lokal" yang didalam terkandung budaya, warisan, tradisi dan Negara lokal. Jika merek lokal tersedia diseluruh dunia, merek lokal tersebut menjadi "raksasa lokal". Dengan menjadi merek global, maka memiliki efek positif pada persepsi konsumen (Özsomer, 2015), yang dapat mempengaruhi sikap dan niat konsumen melalui interaksi kehadiran asing yang memberi sinyal kualitas sebagai strategi komunikasi (Winit et al., 2014).

Persepsi konsumen, kualitas suatu produk pada merek yang sudah mengglobal umumnya melalui laboratorium dalam pengujian, keandalan, daya tahan, umur produk 
(Ghaani Farashahi et al., 2018). Globalitas merek yang dirasakan berdampak positif pada evaluasi merek. Perusahaan dapat menumbuhkan citra merek global dengan menekankan isyarat global. Walaupun merek berasal dari lokal, sehingga dapat memerintahkan harga premium (Winit et al., 2014). Faktor emosional-motivasi memainkan peran yang lebijh besar dalam menentukan keputusan pembelian untuk produk merek global dan nasional dibandingkan merek pribadi (Ravaja et al., 2013).

Citra merek berpengaruh pada keputusan pembelian yang dimediasi oleh kepuasan pelangggan. Implikasi praktisnya pemasar harus mengelola citra mereknya sebagai faktor terpenting yang mempengaruhi keputusan pembelian (Waluya et al., 2019). Desain produk membantu konsumen untuk mendapatkan manfaat dan kepuasan tertinggi, sementara uang yang dikeluarkan untuk melakukan membayar produk sesuai dengan harapan dan kualitas produk (Widyastutir \& Said, 2017). Sementara kualitas berpotensi membantu mencegah efek negatif dari peringkat yang buruk pada citra merek (Casado-Díaz et al., 2017). Khususnya pada dunia fashion, konsumen sangat memperhatikan desain produk. Hampir konsumen kesulitan dan tidak dapat membuat perbandingan kualitas di antara berbagai merek. Ketika komitmen keuangan yang terlibat cukup besar, tetapi tidak dibarengi dengan informasi tentang produk yang memadai. Berdasarkan kondisi tersebut, citra merek memainkan peran dominan dalam menjelaskan persepsi konsumen (Verma \& Gupta, 2014).

Dalam persepsi konsumen, uang atau harga dibayarkan konsumen harus sesuai dengan kualitas produk (Widyastutir \& Said, 2017). Hubungan antara harga dan kualitas produk dikaitkan dengan produk tahan lama, semi tahan lama dan tidak tahan lama. (Verma \& Gupta, 2014). Harga merupakan faktor yang harus dikendalikan secara harmonis dengan tujuan yang ingin dicapai oleh perusahaan. Harga yang rendah dapat meningkatkan kewajaran harga yang dirasakan dan memperkuat niat beli yang lebih tinggi dari strategi harga yang diadakan. Sensitivitas harga berpengaruh moderat secara signifikat terhadap nilai kualitas dan konsumen (Othman \& Rahman, 2016). Bagi konsumen, harga adalah komitmen sekunder untuk membuat keputusan pembelian. Harga yang lebih rendah tidak menjamin kenyamanan belanja. Kepercayaan dalam mengambil keputusa dibangun dari citra merek, toko dan produk yang kuat di pasar (Gunawan et al., 2019). Di satu sisi konsumen jika belanja di toko offline acap kali melihat perbandingan harga antara online dan offline sebelum melakukan keputusan pembelian. Sementara untuk produk toko online, konsumen membandingkan deskripsi produk di toko online berbeda.

Agar unggul dalam produk, pemasar diharapkan mempunyai spesifikasi kualitas produk dan kebijakan pengembalian secara tertulis agar dapat menigkatkan keputusan pembelian terhadap produk (Y. Li et al., 2013, Rokonuzzaman et al., 2021). Khususnya, pada penjualan online terdapat variabel yang sensitif mencegah konsumen membeli produk yaitu kualitas produk dan kebijakan pengembalian (Y. Li et al., 2013). Konsumen menghargai kebijakan pengembalian suatu barang karena dapat memberikan 
perlindungan bagi konsumen ketika produk tidak sesuai. Kebijakan pengembalian dapat memberikan citra toko yang positif yang dapat mempengaruhi keputusan pembelian (Rokonuzzaman et al., 2021).

Kategori harga tidak selalu mencerminkan dimensi kualitas produk yang berbeda. Meskipun harga lebih tinggi yang memiliki spesifikasi produk dan tampilan visual yang unggul tidak menunjukkan kinerja yang unggul (Ghaani Farashahi et al., 2018). Kualitas adalah konsep kompleks multi dimensi, dan tidak ada definisi tunggal yang dapat mencerminkan berbagai perhatiannya. Menurut Garvin (1984) ada lima pendekatan dalam melihat kualitas, yaitu pendekatan transeden, pendekatan berbasis produk, pendekatan berbasis pengguna, pendektan berbasis manufaktur, dan pendektan berbasis nilai (Garvin, 1984). Dalam industri tekstil dan pakaian jadi, dimensi kualitas dikategorikan menjadi lima bagian, yaitu, Pertama, kinerja dapat mempengaruhi persepsi konsumen, Kedua daya tahan mengetahui lama penggunaan produk, Ketiga kemudahan service dalam perawatan dan biaya perawatan, Keempat, kesesuaian dan estetika (mencakup penampilan) untuk mengetahui sejauh mana kinerja dan desain suatu prodk memenuhi standar yang telah ditentukan, Kelima, estetika produk memenuhi kenyaman konsumen melalui tampilannya (Ghaani Farashahi et al., 2018)

Kendati demikian, keputusan pembelian pada barang teknologi berbeda dengan produk lainnya. Keputusan pembelian tidak hanya di pengaruhi citra merek, harga dan kualitas produk. Akan tetapi juga dipengaruhi oleh atribut fisik, keunikan, daya tarik emosional, kemudahan pengoperasian, identitas sosial (Uddin et al., 2015), reputasi bisnis, keseimbangan kualitas produk yang dirasakan, reputasi bisnis, dan intensitas promosi (C. Wang et al., 2021).

Pada proses pembelian terdapat dimensi dalam keputusan pembelian. Yaitu pilihan produk, pilihan merek, pilihan saluran toko, waktu pembelian, jumlah pembelian dan metode pembayaran (Kotler et al., 2018). Konsumen dapat saja memutuskan pembelian secara offline, online ataupun online to offline (C. Wang et al., 2021). Dalam melakukan keputusan pembelian, konsumen dihadapkan dengan dua saluran melalui online atau offline, ataupun kombinasi pesan melalui online dan mengambilnya ke toko. Konsumen tetap harus membayar ekstra saat membeli produk. Jika memilih melalui saluran online maka akan membayar biaya pengiriman tambahan, dan jika membeli melalui saluran toko, mereka membayar biaya transaksi. Konsumen dapat memilih saluran berdasarkan utilitas maksimum mereka (Ghaani Farashahi et al., 2018). Pada dimensi pilihan saluran, Penambahan saluran toko pada online store dapat meningkatkan pengaruh positif pada keputusan pembelian (Hou et al., 2021).

Selain itu, terdapat juga faktor eksternal dalam keputusan pembelian. Sejumlah bukti menyatakan faktor emosional memainkan peran besar dalam pengambilan keputusan pembelian. Perilaku konsumen berdasarkan emosi tersebut dengan pendekatan seperti kegembiraan atau kemarahan (Ravaja et al., 2013). Penilaian evaluatif merek dapat didasarkan pada dua jenis informasi atau masukan yang berbeda 
yaitu (a) informasi deklaratif (atribut merek dan pengetahuan merek ) dan (b) informasi pengalaman terdiri dari emosi dan pengalaman yang diditimbulkan dari merek (Schwarz, 2004, Ravaja et al., 2013). Umumnya perilaku pembelian konsumen dipengaruhi beberapa atribut, merupakan faktor deskriptif yang mencirikan suatu produk. Atribut berkaitan dengan produk adalah citra merek, harga, tempat dan influencer. Sementara atribut yang tidak berkaitan produk dipergaruhi faktor masyarakat, budaya, sosial dan tembat mereka berasal. Konsumen dengan pendapatan rendah akan mempertimbangkan harga sebagai faktor terpenting, sementara yang berpendapatan tinggi akan mempertimbangkan kualitas (Kristina \& Kuswahyuning, 2020).

Secara eksplisit, sebagian atau keseluruhan penerapan variabel citra merek, harga dan kualitas produk disebutkan pada semua artikel penelitian. Dalam klarifikasi mereka, beberapa penelitian hanya membahas citra merek, sebagian lagi membahas kualitas produk. Sebagian lain membahas harga dan kualitas produk. Hanya beberapa penelitian yang membahas secara keseluruhan variabel (Waluya et al., 2019, Ghaani Farashahi et al., 2018, Y. Li et al., 2013). Dalam konteks keputusan pembelian, hasilnya menunjukkan adanya hubungan timbal balik antara citra merek, harga dan kualitas produk.

Penelitian ini mengembangkan model yang menunjukkan hubungan antara citra merek, harga dan kualitas produk pada keputusan pembelian. Singkatnya, harga dan kualitas produk menjadi moderasi pada citra merek. Sementara kualitas produk akan meningkatkan citra merek. Harga yang wajar dan bersaing akan mendorong keputusan pembelian konsumen. Di samping itu kualitas produk yang baik secara konsisten akan menimbulkan kepercayaan konsumen yang outputnya pada keputusan pembelian. Model interkoneksi dari keempat konsep dapat terlihat pada Gambar 4.

Independent Variable (IV) =

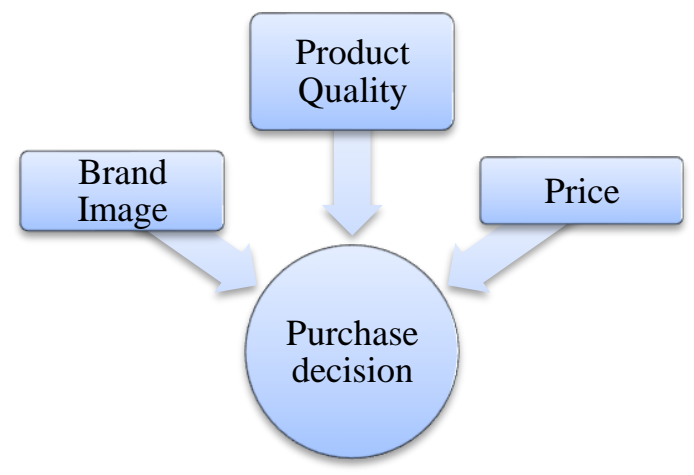

Gambar 4. Kerangka Teoritis Penelitian

Dependent Variable $(\mathrm{DV})=$ 


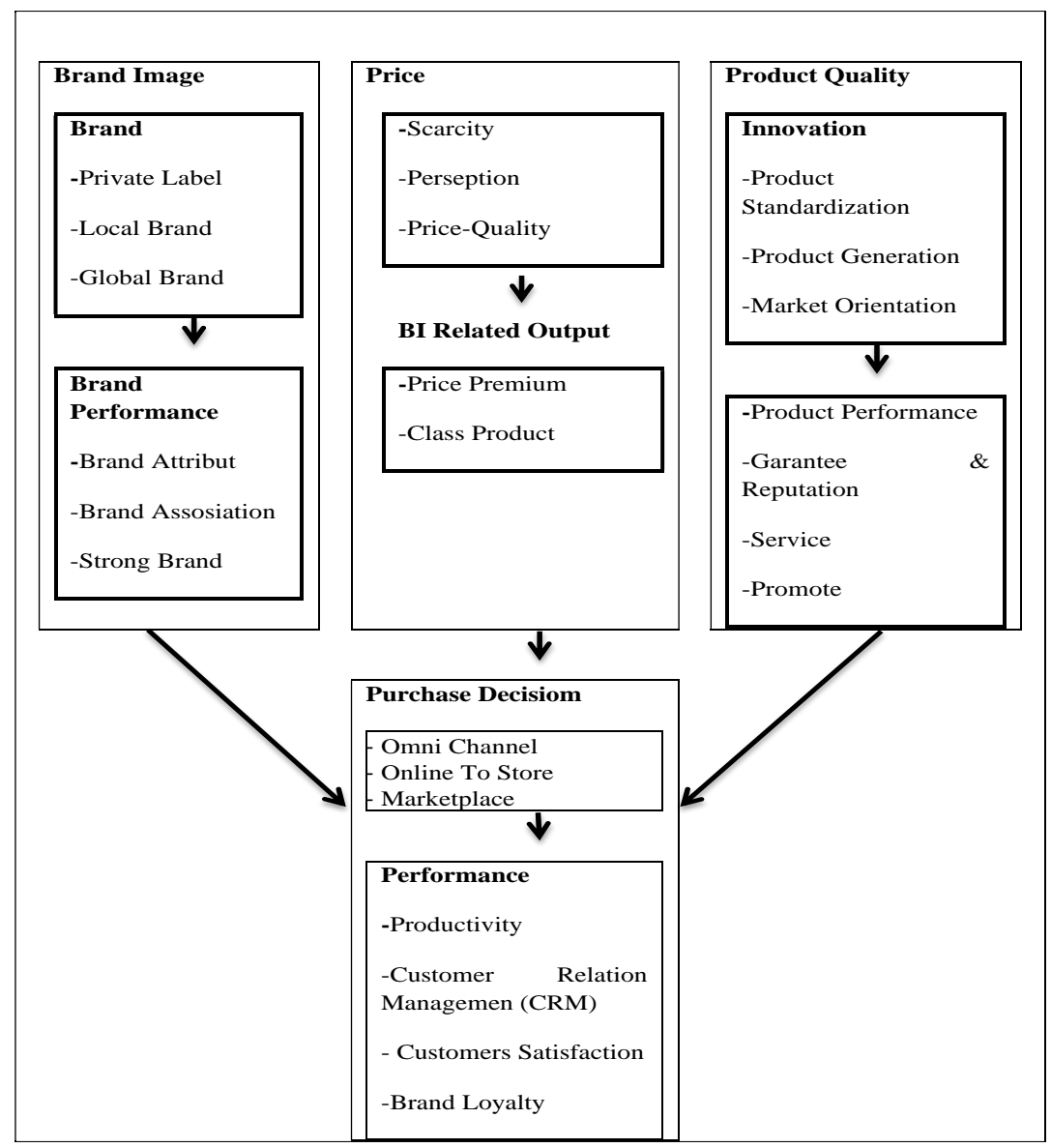

\section{Gambar 5. Model Interkoneksi Citra Merek, Harga, Kualitas Produk Dalam Konteks Keputusan Pembelian}

Keputusan pembelian dalam keterkaitan model adalah variabel yang terpengaruh (variabel dependen). Diantara banyaknya variabel yang mempengaruhi (variabel independen) keputusan pembelian pada berbagai produk usaha dan bisnis.. Secara garis besar terdapat tiga variabel independen yang selalu mempengaruhi keputusan pembelian. Adapun variabel independen tersebut Pertama, Citra merek menjadi faktor yang paling signifikan diikuti sebagai variabel intervening dalam keputusan pembelian (Singh et al., 2018). Konsumen dalam melihat citra merek, akan melihat label, sebagai alat komunikasi efektif dan berguna mempengaruhi keputusan pembelian pelanggan saat ini dan calon pelanggan. Citra merek adalah faktor terbesar yang mempengaruhi keputusan pembelian. Selain itu kualitas produk perlu dikomunikasikan kepada konsumen baru atau pelanggan agar citra merek meningkat (Waluya et al., 2019)

Kedua, Harga, setiap pemasar harus memperhatikan kebijakan penetapan harga pesaing dan daya beli pembeli. Menurunkan harga dapat melemahkan citra mereknya, maka penting untuk menatapkan segmentasi pasar dan posisi produk dalam memilih segmen target yang sesuai terhadap produk. (Verma \& Gupta, 2014). Ketiga Kualitas 
produk pada konteks saat ini bukan hanya mencakup kualitas dari produknya, tapi bermakna luas. Kualitas terhadap pelayanan juga menjadi catatan bagi konsumen. Seperti pada kebijakan pengembalian, perpanjangan garansi penjualan online, cacat produk dan lain sebagainya. Jika perusahaan memudahkan konsumen dalam layanan memuaskan pelanggan. maka kepercayaan kualitas produk dimata konsumen akan meningkat (Y. Li et al., 2013).

Manajemen perusahaan dapat mengambil peran secara totalitas dalam ketiga variabel dependen, yaitu citra merek, harga dan kualitas produk. Perusahaan terkemuka sangat memperhatikan variabel tersebut dengan mengidentifikasi kinerjanya secara periode berkala. Produktivitas dan penjualan perusahaan dapat meningkat, jika memberikan perhatian lebih pada ketiga variabel. Kekuatan dan kelemahan penampilan dan karakteristik kinerja produk dalam berbagai kategori citra merek, harga dan kualitas produk dapat mempengaruhi keputusan pembelian konsumen (Ghaani Farashahi et al., 2018). Apabila dibubuhi dengan iklan yang kontinue berpengaruh signifikan terhadap keputusan pembelian dan loyalitas pelanggan. Bukti empiris mediasi pengambilan keputusan berhubungan antara elemen bauran pemasaran dan loyalitas pelanggan (Adnan et al., 2019).

\section{KESIMPULAN DAN SARAN}

Praktik pelaksanaan citra merek, harga dan kualitas produk disetiap usaha atau bisnis berbeda tergantung organisasinya. Meskipun begitu, hampir perusahaan membangun citra merek dan kualitas untuk investasi jangka panjang. Dengan harga yang mengadaptasi tergantung kebijakan perusahaan dalam melihat data analisis penjualan produk. Kategori citra merek yang berada dipasar adalah merek global, merek lokal (nasional) dan merek pribadi (privat). Masing-masing berkompetisi untuk mencari, mempertahankan dan merperluas pangsa pasar. Persaingan yang ada, merek dengan atribut dan asosiasi merek digunakan untuk memperkuat merek ditengah pasar produk. Operasionalisasi citra merek, adalah cara untuk dikenal dan dipahami oleh konsumen baik segmentasi dan positioning produk.

Harga dan kualitas menjadi komunikasi perusahaan kepada konsumen. Hubungan konsumen akan terjalin ketika produk telah dipakai, memuaskan pelanggan dan menjadi setia terhadap merek suatu produk. Kelangkaan membuat harga diterima semua pihak, namun persepsi harga dimoderasi oleh kualitas produk. Kualitas dimaksud, dalam keterkaitan produk yang mempunyai standarisasi produk. Dengan tujuan pangsa pasar yang jelas, sehingga perusahaan secari periodik dapat memperbaharui fitur dan keunggulan terbaru untuk generasi produk. Perusahaan dapat secara berkala meluncurkan generasi produk terbaru dengan fitur yang diharapkan oleh pelanggan. Perusahaan dapat berinovasi untuk memberikan pelayanan berkualitas, garansi, kinerja produk terbaru dengan melakukan promosi melalui citra merek yang dibangun. 
Konsumen mempunyai hak dalam menentukan keputusan pembelian, baik offline melalui toko, online melalui website, kombinasi offline to online, marketplace atau saluran omnichannel secara garis besar. Perusahaan dapat memanfaatkan dimensi keputusan pembelian yaitu pilihan produk, pilihan merek, pilihan penyalur waktu pembelian. Saat proses keputusan pembelian, perusahaan membangun hubungan jangka panjang, memuaskan pelanggan dengan pelayanan berbasis kualitas, sehingga konsumen setia terhadap merek.

Penelitian ini dibangun secara teoritis dan secara metodologis. Secara teoritis, setiap usaha dan bisnis pada dasarnya berbeda satu sama lain. Dimensi model interkoneksi citra merek, harga dan kualitas produk pada keputusan pembelian dapat dibangun secara bertahap hingga menjadi kokoh. Selanjutnya, tantangan yang dihadapi usaha dan bisnis dapat berubah dari waktu ke waktu mempengaruhi variabel independen, citra merek, harga dan kualitas produk dengan variabel dependen keputusan pembelian. Selain itu, penelitian dapat dilakukan secara metodologis dengan pendekatan lain, seperti kualitatif atau kuantitatif. Pada penelitian kualitatif subjek penelitian mungkin tidak sebanyak subjek penelitian kuantitatif, tetapi data dan diskusi mungkin lebih lengkap dan detail.

Penelitian bagaimanapun tunduk pada beberapa keterbatasan. Pertama, karena analisis hanya menggunakan satu sumber database, Selain itu, artikel penelitian hanya ditinjau berasal dari penerbit tertentu. Kedua, artikel ditinjau dan ditulis pada periode 10 tahun. Kelihatannya sulit untuk melihat perkembangan topik serupa. Mengenai literatur tinjauan sistematis, penelitian masa depan dapat menggunakan lebih dari satu database dan menggunakan periode publikasi yang lebih lama seperti 15 atau 20 tahun. Penelitian selanjutnya diharapkan dapat memberikan hasil yang lebih luas dengan berbagai pemahaman dan pengamatan yang lebih baik tentang bagaimana ilmu pengetahuan terus berkembang.

\section{REFERENSI}

Garvin, D. A. (1984). What Does "Product Quality" Really Mean? Sloan Management Review, 26(1), 25-43.

Kotler, \& Amstrong. (2012). Principles of Marketing. In The Economic Journal (Vol. 38, Issue 151). https://doi.org/10.2307/2224326

Kotler, \& Keller. (2016). Marketing Management. In Boletin cultural e informativo - (Vol. 22). Pearson.

Ngo, H. Q., Nguyen, T. Q., Long, N. T., van Tran, T., \& Hoang, T. M. (2019). Factors affecting brand and student decision buying fresh milk: A case study in Ho Chi Minh City, Vietnam. Journal of Asian Finance, Economics and Business, 6(3), 247-258. https://doi.org/10.13106/jafeb.2019.vol6.no3.247 
Sallam, M. A. (2016). The Impact of Brand Image and Corporate Branding on Consumer's Choice: The Role of Brand Equity. International Journal of Marketing Studies, 8(1), 98. https://doi.org/10.5539/ijms.v8n1p98

Waluya, A. I., Iqbal, M. A., \& Indradewa, R. (2019). How product quality, brand image, and customer satisfaction affect the purchase decisions of Indonesian automotive customers. International Journal of Services, Economics and Management, 10(2), 177-193. https://doi.org/10.1504/IJSEM.2019.100944

Wang, C., Wang, Y., Wang, J., Xiao, J., \& Liu, J. (2021). Factors influencing consumers' purchase decision-making in $\mathrm{O} 2 \mathrm{O}$ business model: Evidence from consumers' overall evaluation. Journal of Retailing and Consumer Services, 61(September 2020), 102565. https://doi.org/10.1016/j.jretconser.2021.102565

Wijaya, B. S. (2012). Dimensions of Brand Image: A Conceptual Review from the Perspective of Brand Communication. https://doi.org/10.13140/ejbm.2013.55.65 